\title{
Cranial bone reconstruction with customized implants after trauma
}

\author{
Reconstrucción ósea de defectos craneales secundarios a traumatismo con implantes \\ personalizados
}

\author{
Ricardo Cienfuegos ${ }^{1,2 *}$, Gerardo Fernández ${ }^{2,3}$, Aída Cruz ${ }^{4}$ and Eduardo Sierra ${ }^{4}$ \\ ${ }^{1}$ Education Division, Unidad Médica de Alta Especialidad (UMAE), Traumatología y Ortopedia Lomas Verdes, Instituto Mexicano del Seguro Social \\ (IMSS); ${ }^{2}$ Centro Médico ABC Observatorio; ${ }^{3}$ Department of Plastic Surgery, Instituto Nacional de Pediatría; ${ }^{4}$ UMAE Traumatología y Ortopedia \\ Lomas Verdes, IMSS. Mexico City, Mexico
}

\begin{abstract}
Introduction: Cranial defects due to trauma are frequent. They are usually repaired in a secondary fashion due to features such as syndrome of the trephined, for brain protection and for cosmetic purposes. Historically, various materials have been used for reconstruction. Case reports: Five cases of patients reconstructed with customized polyetheretherketone (PEEK) 0 polymethyl methacrylate (PMMA) implants are presented. Defects involved the frontal bone, superior orbital rim and orbital roof in four cases, and the lateral area of the frontal bone, the temporoparietal area and the border of the occipital bone in one. In four patients, reconstruction took place between 6 and 12 months after the injury; in one patient, after 25 years. Two cases required tissue expansion before placing the implant. Results: Four patients evolved favorably, with improvement in neurologic symptoms and adequate shape and contour, plus adequate healing of the scalp flaps. One patient had an infection due to Staphylococcus aureus, attributed to a mucocele and fistula between the airway and the cranial cavity, leading to removal of the implant. Conclusions: Customized implants are a useful resource for cranial defects. They offer satisfactory results, both functional and cosmetic. Precautions should be taken in treating injuries that involve the frontal sinus, to ensure there is no communication between the airway and the cranial cavity.
\end{abstract}

KEY WORDS: PEEK. PMMA. Polyetheretherketone. Polymethyl methacrylate. Reconstructive surgical procedures. Prostheses and implants.

\section{Resumen}

Introducción: Los defectos craneales secundarios a traumatismos son frecuentes. Por lo común se reparan de forma secundaria por sintomatología como el síndrome del paciente trepanado, por protección cerebral y por el aspecto cosmético. Históricamente se han utilizado diversos materiales para la reconstrucción. Casos clínicos: Se presentan cinco casos de pacientes reconstruidos con implantes personalizados de polieteretercetona (PEEK) o polimetilmetacrilato poroso (PMMA). Las localizaciones afectaron el frontal, el borde orbitario superior y el techo orbitario en cuatro casos, y la porción lateral del frontal, la zona temporoparietal y el borde del occipital en un caso. La reconstrucción en cuatro pacientes fue entre 6 y 12 meses después de la lesión, y en un caso después de 25 años. En dos casos se requirió expansión tisular antes de colocar el implante. Resultados: Cuatro pacientes evolucionaron favorablemente, con mejoría de los síntomas neurológicos, forma y

\author{
Correspondence: \\ ${ }^{*}$ Ricardo Cienfuegos \\ Sur 136, 116-111 \\ Col. Las Américas, Del. Álvaro Obregón \\ C.P. 01120, Ciudad de México, México \\ E-mail: rcienfuegos@usa.net
}

Date of reception: 22-03-2018

Date of acceptance: 26-04-2018

DOI: $10.24875 / C I R U E . M 18000043$
Cir Cir. 2018;86:258-264

Contents available at PubMed www.cirugiaycirujanos.com 
contorno adecuados, así como un proceso de cicatrización adecuada de los colgajos de piel cabelluda. Un paciente present infección por Staphylococcus aureus, atribuida a la presencia de un mucocele y una fístula de la vía aérea a la cavidad craneal, lo que hizo necesario retirar el implante. Conclusiones: Los implantes personalizados son un recurso útil para defectos óseos craneales. Brindan resultados satisfactorios desde el punto de vista funcional y cosmético. Deben tomarse precauciones respecto al tratamiento de las lesiones que afecten el seno frontal, para evitar la comunicación entre la vía aérea y la cavidad craneal.

PALABRAS CLAVE: PEEK. PMMA. Polieteretercetona. Polimetilmetacrilato. Procedimientos quirúrgicos reconstructivos. Prótesis e implantes.

\section{Introduction}

Cranial skeletal defects secondary to trauma are common owing to the high frequency of road accidents, urban violence and even contact sports. Some bone defects can also be due to infections, surgical procedures or tumors. Neurosurgical treatment of cranial traumas includes craniotomies and removal of bone segments, due to exposed fractures and intracranial lesions such as hematomas. Bone defects are secondarily repaired, since in many cases primary repair is not indicated due to the possibility of infection. In view of this panorama, cranial reconstruction has as its purpose both the functional and the cosmetic aspect. The functional aspect considers the relief of neurological symptoms due to the so-called "sinking skin flap syndrome" or "syndrome of the trephined, as well as the protection of intracranial contents'. Restitution of the cosmetic aspect should also be considered, primarily if the bone defect is close to the face, as it occurs with frontal defects (Fig. 1). For the repair of skull bone losses, autologous, heterologous and alloplastic materials can be used, with the latter including metals and plastics.

The purpose of this work is to present the results of five cases treated by reconstruction of the cranial vault with personalized alloplastic implants, four made out of polyetheretherketone (PEEK) and one of porous polymethyl methacrylate (PMMA). These types of alloplastic materials offer their permanence for an indefinite time as an advantage; they provide mechanical stability, adaptability to the zone to be reconstructed, biocompatibility and protection to the intracranial content, in addition to a good cosmetic result that includes restoring symmetry. They can be sterilized in repeated occasions without their properties being altered, and are compatible with magnetic resonance and computed tomography. Another benefit to be considered is the improvement in the symptoms associated with the sinking skin flap syndrome $e^{2,3}$.

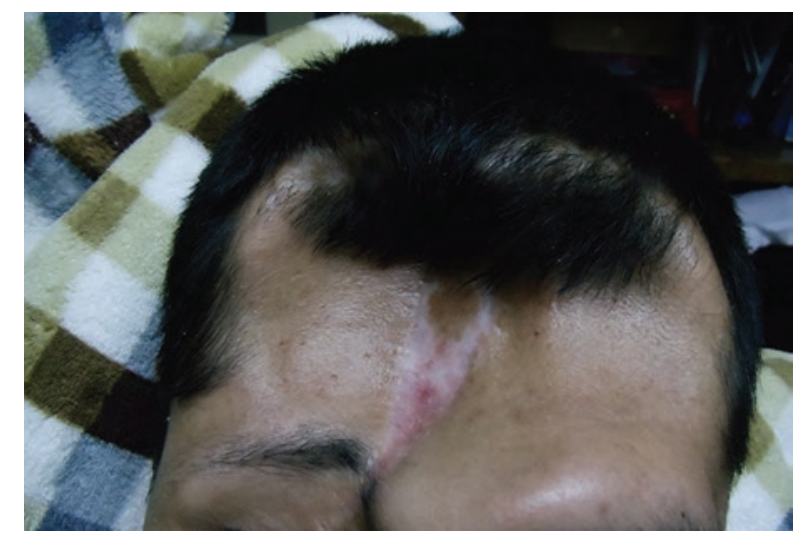

Figure 1. Frontal and supraorbital border defect and sinking skin flap (case 4, Table1).

\section{Clinical cases}

A review was made of patients subjected to surgical treatment by the authors for reconstruction of cranial bone defects that were intervened between 2008 and 2016, both in a public (High Specialty Medical Unit, Lomas Verdes Traumatology and Orthopedics Hospital) and in a private hospital (ABC Medical Center) in Mexico City.

Bone defects were secondary to cranioencephalic or craniofacial trauma, as well as to craniotomies subsequent to trauma. The patients were assessed both clinically and by imaging using computerized tomography with thin slices $(1 \mathrm{~mm})$.

Treatment consisted of customized cranial implants in five male patients. Ages ranged from 15 to 50 years, with a mean of 29.2 years. The areas to be reconstructed were the frontal region associated with the supraorbital border and, partially, the orbital roof in four cases, and the lateral portion of the frontal bone, the temporoparietal area and the occipital border in one case. Four of the five patients had also sustained facial fractures. For the manufacture of the customized implant, a computed tomography with $1 \mathrm{~mm}$-thick slices was performed in all cases, which was delivered to the manufacturer. 
Four PEEK implants (DePuy Synthes, West Chester, PA, USA) and one PMMA implant (Zimme Biomet, Warsaw, IN, USA) were placed (Table 1).
To carry out the reconstruction, it was deemed convenient for patients to have between 6 and 12 months of postoperative evolution with the cranial bone defect.

Table 1. Characteristics of the five cases and customized implants images

\begin{tabular}{|c|c|c|c|c|c|c|}
\hline Case & $\begin{array}{l}\text { Gender } \\
\text { and age }\end{array}$ & $\begin{array}{l}\text { Defect localization and } \\
\text { dimensions }\end{array}$ & $\begin{array}{l}\text { Implant } \\
\text { material }\end{array}$ & Surgical times & Complications & Implant image \\
\hline 1 & $\begin{array}{l}\text { Male } \\
24 \text { years }\end{array}$ & $\begin{array}{l}\text { Left frontoorbital } \\
(13 \times 10 \mathrm{~cm})\end{array}$ & PEEK & $\begin{array}{l}\text { Two: } \\
\text { - Parietooccipital tissue } \\
\text { expander } \\
\text { - Expander removal and } \\
\text { implant placement }\end{array}$ & No & \\
\hline 2 & $\begin{array}{l}\text { Male } \\
15 \text { years }\end{array}$ & $\begin{array}{l}\text { Left frontal, parietal, } \\
\text { temporal and occipital } \\
(20 \times 16 \mathrm{~cm})\end{array}$ & PEEK & One & No & \\
\hline 3 & $\begin{array}{l}\text { Male } \\
27 \text { years }\end{array}$ & $\begin{array}{l}\text { Right orbital roof } \\
\text { Right frontal, } \\
\text { parietal and temporal } \\
(12.4 \times 12 \mathrm{~cm})\end{array}$ & PMMA & One & $\begin{array}{l}\text { Yes: frontal } \\
\text { collection due to } \\
\text { mucocele and } \\
\text { fistula at } \\
11 \text { months. } \\
\text { Implant removal; } \\
\text { positive culture for } \\
\text { S. aureus }\end{array}$ & \\
\hline 4 & $\begin{array}{l}\text { Male } \\
30 \text { years }\end{array}$ & $\begin{array}{l}\text { Bilateral frontal, parietal } \\
\text { and temporal } \\
(18.6 \times 12 \mathrm{~cm})\end{array}$ & PEEK & $\begin{array}{l}\text { Three: } \\
\text { Osteotomy and right } \\
\text { zygomatic bone } \\
\text { reconstruction; } \\
\text { parietooccipital tissue } \\
\text { expander placement } \\
\text { Expander removal } \\
\text { Implant placement }\end{array}$ & No & \\
\hline 5 & $\begin{array}{l}\text { Male } \\
50 \text { years }\end{array}$ & $\begin{array}{l}\text { Left frontal and supraorbital } \\
(7.7 \times 2.8 \mathrm{~cm})\end{array}$ & PEEK & $\begin{array}{l}\text { One: } \\
\text { Osteotomies and fixation of } \\
\text { both zygomatic bones; mesh } \\
\text { on both orbital floors; middle } \\
\text { third soft tissue suspension; } \\
\text { implant placement }\end{array}$ & No & \\
\hline
\end{tabular}


Surgical wounds healing was clinically analyzed, watching for the presence fistulas, injured tissue areas or infection. One case of multiple trauma sequelae, with facial fractures and bone loss of the frontal sinus anterior wall and partial loss of the left orbital roof, which had more than 25 years of evolution, was included.

Surgical procedures were carried out under general anesthesia and the implants were placed through the scar of the previous coronal access (Fig. 2), with the exception of the youngest patient (aged 15 years), in whom the implant was placed through the lateral skull surgical access of initial treatment. Cranial bone loss reconstruction with the customized implant was carried out in a single surgical time in three of the five patients; in the fourth case, in two surgical times, and in the fifth case, in three surgical times. In the latter two patients, sequential procedures were executed: initially, a tissue expander was placed in both in order to improve skin availability for reconstruction, since the scalp skin flap was retracted and was considered insufficient to cover the reconstructed area with the implant (Fig. 3). Both expanders (of remote valve) were placed in the parietooccipital region. One of these cases developed cellulitis in the expansion area, and removing the expander was therefore necessary, in addition to administering antimicrobial treatment. The customized implant was placed 3 months later in order to avoid scalp retraction, after checking for the absence of infection.

The implants were fixed to the receiving area with titanium plates and 1.5-mm diameter screws. Stitches were placed onto the dura mater, which were extracted through the holes of the implant and knotted to it in order for the meninx to be brought together with the internal face of the implant (Fig. 4). The coronal access was prepared in two planes, with 3-0 and 4-0 nylon, respectively. A closed drain with a vacuum system was used for 3 days in all patients to avoid subcutaneous serohematic collection, in addition to favoring adherence of the flap to the bed, as well as to the implant. The scalp sutures were removed 8 days after the intervention. In all cases, antimicrobial was administered, which was started prior to the intervention and was continued for 7 days.

As a postoperative control, computed tomography was performed in all cases, in addition to clinical evolution monitoring.

\section{Results}

The skull bone losses of five patients, all of traumatic origin, were reconstructed using personalized

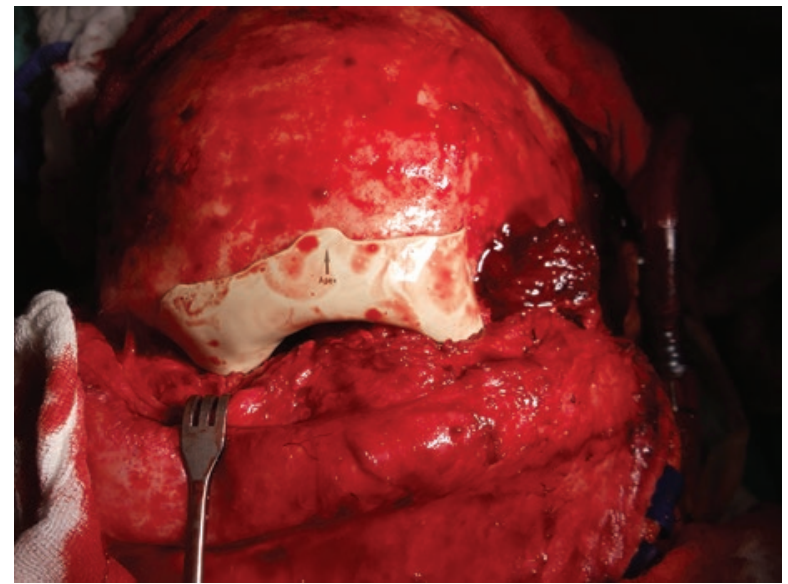

Figure 2. Coronal access to place the implant for frontoorbitary bone loss repair (case 5, Table 1).

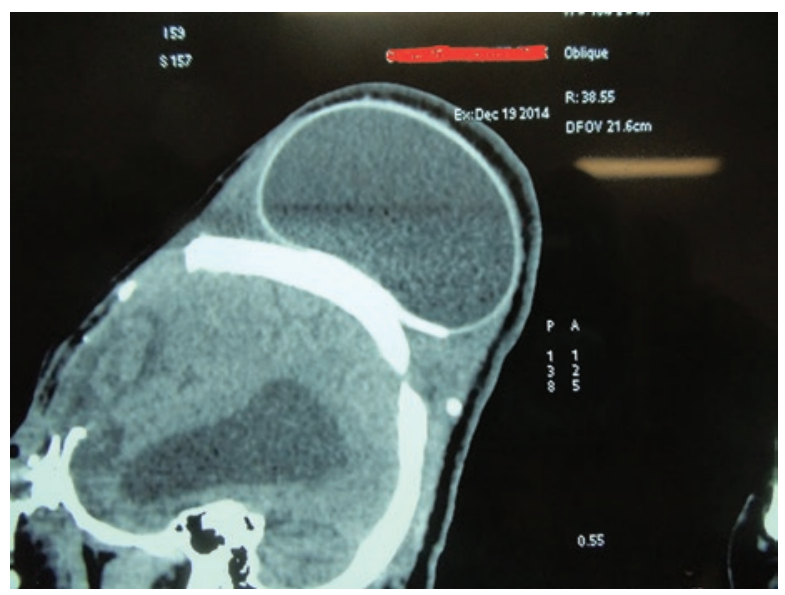

Figure 3. Tomographic image of the tissue expander on the skull posterior portion.

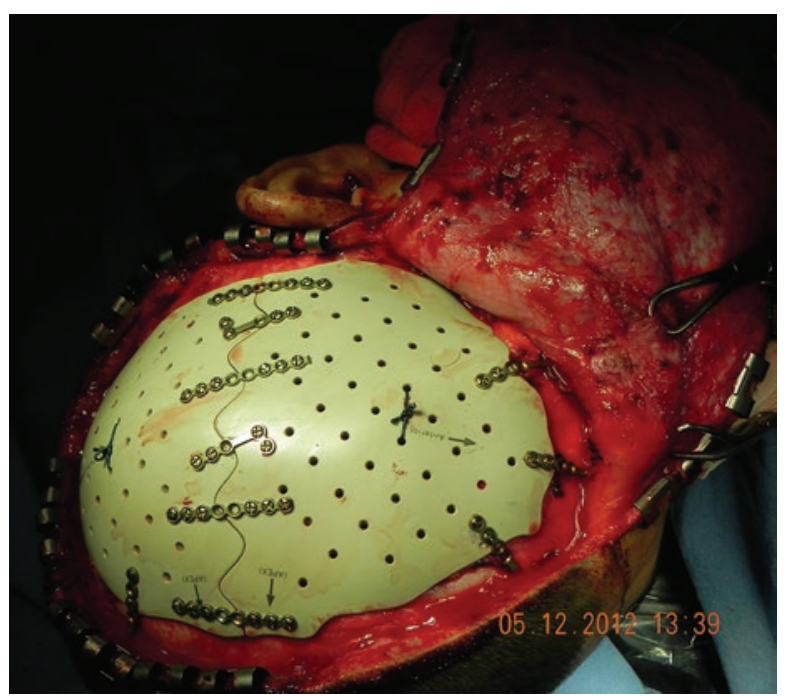

Figure 4. Two-piece customized implant, placed on a lateral defect of the skull. Note the placement of sutures to bring the implant closer to the dura mater (case 2, Table 1). 
implants, custom-made based on a computed tomography. Four PEEK implants and one PMMA implant were used. All defects were reconstructed on the sequel phase, not less than 6 to 12 months after initial treatment. One of the cases (the oldest patient) underwent reconstruction 25 years after the causal accident.

As already mentioned, in three of the five cases, the reconstruction was carried out in a single surgical time. In the patient treated in two surgical times, the tissue expander was placed in the first intervention. It was gradually filled until a sufficient volume was obtained, and then the removal of the expander and placement of the implant in the second surgical time were planned. Both procedures were carried out uneventfully (Fig. 5).

In the patient treated in three surgical times, in the first intervention, osteotomy with zygomatic bone fracture reduction and fixation was performed, as well as orbital medial floor and wall reconstruction (due to sequelae of zygomatic bone fractures not treated in initial care), in addition to the placement of the tissue expander. A few days before the date planned for the removal of the expander and placement of the implant in the second surgical time, the presence of cutaneous hyperemia was detected, which was classified as cellulitis and made it necessary for the expander to be removed. The tomographic study did not reveal subcutaneous or intracranial cavity collections. When the expander was removed, no purulent material was found, and a good clinical response was obtained with the use of clindamycin for 10 days. Expander and adjacent tissue cultures were negative for bacterial development. To avoid retraction of the expanded skin flap, supported by the result of the trans-operative cultures and patient evolution, carrying out the cranial reconstruction with the implant 3 months after removing the tissue expander was decided, in a third surgical time. The patient evolved without further complications (Fig. 6).

Surgical accesses healed without complications in all cases.

In all five cases, the dimensions of the implant were ideal, since there was no need to modify the recipient area or the implant at the time of placement. Fixation of all the implants in the receiving area with titanium plates and $1.5 \mathrm{~mm}$-diameter screws was carried out without major difficulties and evolved uneventfully.

Four months after the customized PMMA implant was placed, the patient presented with clinical signs and symptoms characterized by frontal cutaneous

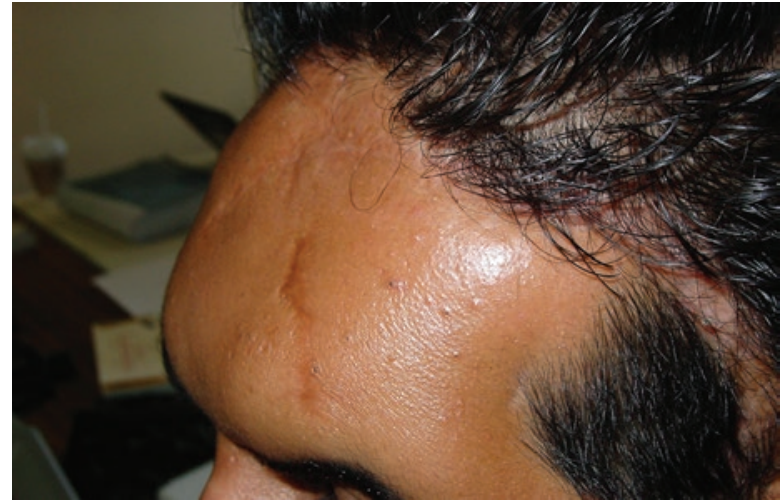

Figure 5. Evolution 18 months after reconstruction with left frontoorbital implant (case 1, Table 1).

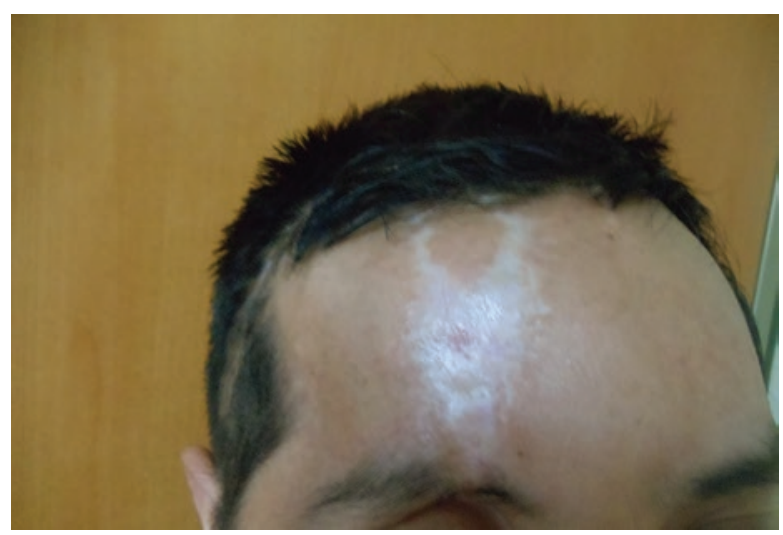

Figure 6. Case 4 postoperative image at 24 months of postoperative evolution. Notice the frontoorbital zone contour (Fig. 1 and Table 1).

lesions (papules) and subcutaneous fluctuance of the reconstructed region. Computed tomography revealed the presence of nasofrontal region collection consistent with mucocele. Removing the implant was decided. During the removal operation, purulent material $(4 \mathrm{~mL})$ was found, which was sent for culture. A bone defect was discovered in the lower portion of the frontal bone, which communicated with the nose. The bone defect was treated by mucosal abrasion, bone scarification and filling with muscle and sterile gelatin sponge $\left(\right.$ Gelfoam $^{\circledR}$ ), and was covered with a local periosteum small skin flap. The culture reported the presence of Staphylococcus aureus, and vancomycin with imipenem was therefore administered for 10 days. Postoperative status after 10 months is satisfactory. In addition to a favorable clinical evolution, tomographic studies show obliteration of the fistula; there is no persistence of the bone defect or mucocele formation. The patient is waiting for a new cranial reconstruction.

Our patients have undergone long follow-ups, of up to 24 months, during which we have been able to 
verify adequate healing, stability of the implant and that the shape of the reconstructed area is recovering symmetry and remains unchanged (except in the case of implant removal).

In patients who undergo craniectomy, the so-called "syndrome of the trephined" or "sinking skin flap syndrome", characterized by motor, cognitive and language deficits, headache and other symptoms, has been described ${ }^{4}$. Total skull thickness defects reconstruction improves these manifestations ${ }^{5}$. Four of our patients had suffered total thickness cranial bone loss and had symptoms consistent with this syndrome (headaches, dizziness, and gait disorders). A quantitative measurement of these neurological alterations was not preoperatively performed. However, in the postoperative period, the patients referred a qualitatively marked decrease in the intensity of headache and in the presence of dizziness, as well as an improvement in gait. These changes became evident in the third postoperative month and thereafter.

\section{Discussion}

Cranial defects reconstruction is a procedure that has been practiced for centuries. A variety of materials has been used, which range from dog bone or autologous bone to gold ${ }^{2}$. Reconstruction has as its fundamental objective the protection of the brain, the esthetic aspect and also, within the functional scope, to decrease sinking skin flap syndrome manifestations ${ }^{2,4-6}$.

Currently, a wide variety of biological and alloplastic materials are available for the reconstruction of cranial bone losses. Autologous bone can be used, although its disadvantages include the possibility of bone resorption, longer surgical time, bleeding and morbidity for the donor area ${ }^{2,3}$.

Alloplastic materials include titanium mesh, with the advantages of being biocompatible and malleable, but with the disadvantage of not providing a good contour in areas of considerable dimensions or in areas such as the frontal region, in addition to the fact that it can cause artifacts in imaging studies ${ }^{3}$. Methylmethacrylate has been widely used, but it is difficult to mold and can cause injuries in adjacent tissues due to the exothermic reaction produced during its polymerization ${ }^{3}$.

The use of computer-designed implants is not new, since it started in $1995^{7}$. This type of implants, which can both be made out of PEEK and PMMA, offer multiple advantages. PEEK and PMMA implants can be bored into with a drill bit and have screws inserted to fix them; similarly, in case of using self-drilling screws, these can be inserted without problems. It should also be highlighted that surgical time is shortened and morbidity of the donor area is reduced. Unlike autologous bone, it is not necessary to wait for graft consolidation, nor is there a risk for resorption. Another benefit is resistance, reconstructed skull contour restitution and restoration of symmetry, a very noticeable situation when the defect is located in the frontal region.

Three requirements of vital importance are a bed with adequate vascularity, stable and sufficient skin to cover the implant, and absence of local infection. Whatever the severity of the injury, initial treatment should contribute to these conditions focusing on future reconstruction. Should there be skin flap retraction making it difficult to cover the implant or involving the risk of exposure, previous tissue expansion can be resorted to. In case the defect has communication with the frontal sinus, it is essential to isolate the latter in order to reduce the risk of infection by continuity with the airway.

In our series, we found that no adjustment of the implants was required when they were placed in the receiving area. In our experience, in order to reduce the dead space between the implant and the dura mater surface we placed some sutures ("reins") to bring the dura mater together with the internal face of the implant. The use of drains with suction helps to avoid the formation of hematomas and seromas, and it favors adherence of the scalp skin flap to the bed constituted by the implant as well.

We consider that the infection presented by the patient reconstructed with the PMMA implant was directly related to mucocele and the existing fistula, due to the communication between the upper portion of the upper airway and the frontal sinus. This point should certainly be kept in mind when treating fractures that affect the frontal sinus ${ }^{8,9}$. Ten months after the implant removal, the patient is asymptomatic, with a favorable evolution and no imaging data consistent with recurrence of the fistulous tract. Nevertheless, we believe it would be prudent waiting a few more months to try a new reconstruction of the frontal region.

It would be important raising awareness about the "sinking skin flap syndrome" or "syndrome of the trephined" clinical features among specialists who treat patients with defects of the cranial vault. A possible line of investigation would be a detailed documentation of the manifestations of the syndrome, as well as of its mitigation or resolution thanks to reconstructive procedures. Another relevant line would seek to 
establish specific criteria on what type of defects are susceptible to reconstruction with titanium mesh, prefabricated implants or bone grafts, both from the point of view of dimensions and, possibly, of their anatomical location.

\section{Conclusions}

Cranial reconstruction is a necessity for patients undergoing craniectomy with bone loss, not only for cosmetic purposes, but also to improve the neurological symptoms secondary to bone loss known as "syndrome of the trephined" or "sinking skin flap syndrome", in addition to providing protection to the brain.

According to some authors, reconstruction of cranial defects with customized implants made out of PEEK or PMMA is a good solution; there is not enough evidence to demonstrate the superiority of one of these materials over the other ${ }^{10}$. Our series is small, of five cases, among whom only one had complications due to infection, which was attributable to a fistula that connected the upper part of the nasal cavity with the frontal sinus and to the presence of mucocele; that case was the only one where a PMMA implant was used. Another point to consider is the dead space between the surface of the brain and the internal face of the implant; it is recommended for this space not to exceed $2 \mathrm{~cm}$, in order to avoid the formation of hematomas and seromas, which are susceptible to infection ${ }^{11}$. We have managed to solve this situation by placing sutures to bring the dura mater close to the implant.

The three-dimensional printing technology applied to craniofacial skeleton surgery has continuously improved since its invention in the $1980 \mathrm{~s}^{12}$. Today, there is the option of using custom manufactured prostheses, based on a computed tomography, to repair bone losses. New materials have greater biocompatibility, are light and resistant, and can be stably fixed with plates and screws onto the receiving area. In the specific case of customized implants, they constitute an integral and practical solution that provides excellent cosmetic and functional results for this type of reconstructions. The specific indications for reconstruction with customized implants still need to be more precisely defined.

\section{References}

1. Manson PN, Crawley WA, Hoopes JE. Frontal cranioplasty: risk factors and choice of cranial vault reconstructive material. Plast Reconstr Surg. 1986;77:888-900.

2. Jonkergouw J, van de Vijfeijken SECM, Nout E, Theys T, van de Casteele $\mathrm{E}$, Folkersma $\mathrm{H}$, et al. Outcome in patient-specific PEEK cranioplasty: a two-center cohort study of 40 implants. J Craniomaxillofac Surg. 2016;44:1266-72.

3. Alonso-Rodríguez E, Cebrián JL, Nieto MJ, del Castillo JL, Hernández-Godoy J, Burgueño M. Polyetheretherketone custom-made implants for craniofacial defects: report of 14 cases and review of the literature. J Craniomaxillofac Surg. 2015;43:1232-8.

4. Ashayeri K, Jackson EM, Huang J, Brem H, Gordon CR. Syndrome of the trephined: a systematic review. Neurosurgery. 2016;79:525-34.

5. Isago T, Nozaki M, Kikuchi Y, Honda T, Nakazawa H. Sinking skin flap syndrome: a case of improved cerebral blood flow after cranioplasty. Ann Plast Surg. 2004:53:288-92.

6. Zegers $\mathrm{T}$, ter Laak-Poort M, Koper D, Lethaus B, Kessler P. The therapeutic effect of patient-specific implants in cranioplasty. J Craniomaxillofac Surg. 2017;45:82-6.

7. Gerbino G, Zavattero E, Zenga F, Bianchi FA, Garzino-Demo P, Berrone S. Primary and secondary reconstruction of complex craniofacial defects using polietheretherketone custom-made implants. J Craniomaxillofac Surg. 2015;43:1356-63.

8. Rodríguez ED, Stanwix MG, Nam AJ, St Hilaire H, Simmons OP, Christy MR, et al. Twenty-six year experience treating frontal sinus fractures: a novel algorithm based on anatomical fracture pattern and failure of conventional techniques. Plast Reconstr Surg. 2008;122:1850-66.

9. Zubillaga Rodríguez D, Lora Pablos MI, Falguera Uceda R, Díez Lobato G, Sánchez Aniceto G. Frontal sinus obliteration after trauma: analysis of bone regeneration for two selected methods. Int J Oral Maxillofac Surg. 2014;43:827-33.

10. Iaccarino C, Viaroli E, Fricia M, Serchi E, Poli T, Servadei F. Preliminary results of a prospective study on methods of cranial reconstruction. J Oral Maxillofac Surg. 2015;73:2375-8.

11. Kumar AR, Tantawi D, Armonda R, Valerio I. Advanced cranial reconstruction using intracranial free flaps and cranial bone grafts: an algorithmic approach developed from the modern battlefield. Plast Reconstr Surg. 2012;130:1101-8.

12. Jacobs CA, Lin AY. A new classification of three-dimensional printing technologies: systematic review of three-dimensional printing for patient-specific craniomaxillofacial surgery. Plast Reconstr Surg. 2017;139:1211-20. 